Article

\title{
An Integrated Biomass Production and Conversion Process for Sustainable Bioenergy
}

\section{Weidong Huang}

Environmental Division, School of Earth and Space Science, University of Science and Technology of China, Hefei 230026, China; E-Mail: huangwd@ustc.edu.cn; Tel.: +86-551-6360-6631

Academic Editor: Marc A. Rosen

Received: 22 September 2014 / Accepted: 29 December 2014 / Published: 6 January 2015

\begin{abstract}
There is not enough land for the current bioenergy production process because of its low annual yield per unit land. In the present paper, an integrated biomass production and conversion process for sustainable bioenergy is proposed and analyzed. The wastes from the biomass conversion process, including waste water, gas and solid are treated or utilized by the biomass production process in the integrated process. Analysis of the integrated process including the production of water hyacinth and digestion for methane in a tropical area demonstrates several major advantages of the integrated process. (1) The net annual yield of methane per unit land can reach 29.0 and $55.6 \mathrm{~km}^{3} / \mathrm{h}$ for the present and future (2040) respectively, which are mainly due to the high yield of water hyacinth, high biomethane yield and low energy input. The land demand for the proposed process accounts for about $1 \%$ of the world's land to meet the current global automobile fuels or electricity consumption; (2) A closed cycle of nutrients provides the fertilizer for biomass production and waste treatment, and thus reduces the energy input; (3) The proposed process can be applied in agriculturally marginal land, which will not compete with food production. Therefore, it may be a good alternative energy technology for the future.
\end{abstract}

Keywords: bioenergy; anaerobic digestion; integrated process; water hyacinth

\section{Introduction}

Energy security and emission of massive quantity of $\mathrm{CO}_{2}$ associated with the greenhouse effect of present energy infrastructure have raised attention to the bioenergy [1,2]. There is a great need for sufficient renewable energy supplies which do not compete with food supply and cause environmental 
harm, as the global demand for energy and food will double within the coming 50 years [3,4]. Current food based on biofuel production not only competes for fertile land with food production, increases pollution from fertilizers and pesticides, and threatens biodiversity when plenty of natural land is applied to biofuel production [5], but also provides only a small part of the energy demand [6]. Biofuel based on agriculturally degraded lands to produce grass or wood [7] has low biomass yield [8]. Conversion of these lignocellulosic biomass to bioethanol or synthesis fuel [9] has low efficiency and high energy input [10]. Both of them result in the low net annual biofuel yield per unit land, such as $4400 \mathrm{~L} / \mathrm{km}^{2} /$ year bioethanol produced in the Midwest of the US [8], so a large amount of land is needed to replace the fossil fuel with the renewable biofuel: 58\% of US land area is needed for production of biofuel to replace the current oil consumption of the United States transportation sector [11]. The low yield of the biomass also limits the scale of the biofuel production factory which leads to high cost of the biofuel. The independent production and conversion of the biomass as shown in Figure 1 also increases the energy input and production cost.

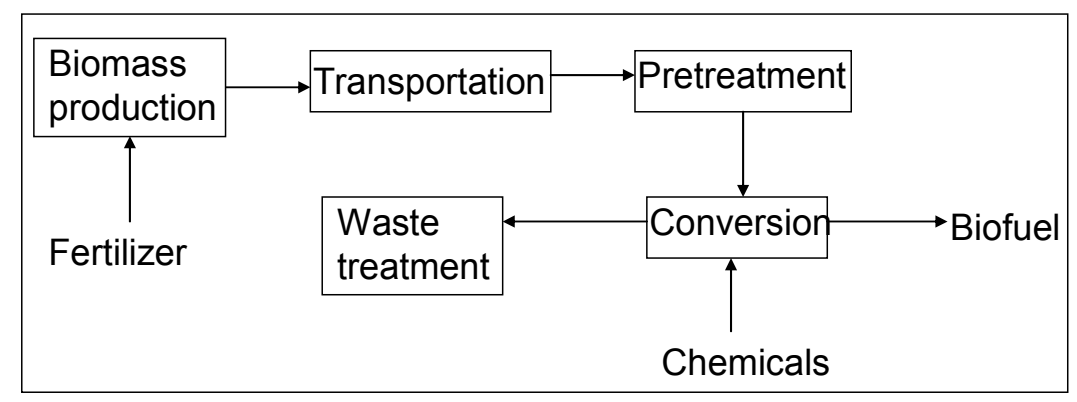

Ordinary bioconversion process for production of biofuel

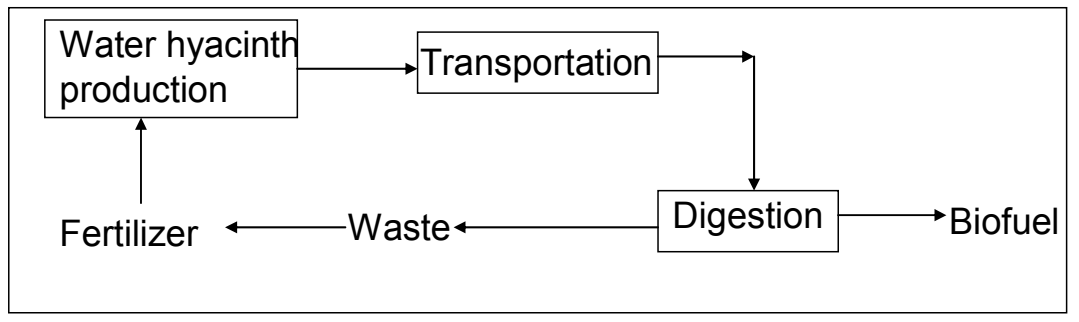

Integrated biomass production and digestion process for biofuel

Figure 1. Ordinary and integrated biomass production and conversion process for production of biofuel. Virtues of Integrated Water hyacinth production and digestion process (down): (1) use waste of bioconversion process as fertilizer for biomass production; (2) does not need to input fertilizer, chemicals for biomass production; (3) does not need pretreatment of biomass and waste treatment for digestion.

Recently, a hybrid hydrogen-carbon process is proposed to reduce the land area requirement to $920,000 \mathrm{~km}^{2}$ for the US transportation sector [11], but a renewable hydrogen production is needed to provide 239 billion $\mathrm{kg}$ hydrogen per year and the technology for large scale hydrogen production with low cost is still in development [12].

To overcome the environmental challenges and land limitation associated with bioenergy, we propose to integrate the biomass production and conversion process to obtain high bioenergy yield so 
as to decrease land requirement and reduce environmental harm [13]. We estimate the net energy of the processes produced in a unit land over a year.

\section{Integrated Biomass Production and Conversion Process for Bioenergy Production}

Current bioenergy production process (Figure $1 \mathrm{up)} \mathrm{includes} \mathrm{the} \mathrm{biomass} \mathrm{production,} \mathrm{transportation,}$ pretreatment, conversion and waste treatment [14]. More than ten biomass conversion methods have been extensively studied [15], and the digestion process is one of the mature processes [16]. However, the biomass production process is not dependent on the biomass conversion process. Fertilizer and many chemicals are needed for production and conversion of biomass.

In our proposal (Figure 1), a floating aquatic plant with low lignin content grows in a greenhouse to produce biomass continually and is then digested to biogas [17]; methane and carbon dioxide in biogas are separated with a washing process [18], methane is output as fuel of automobiles [19], and/or burned to produce electricity through combined gas and steam cycle power generation system. The pretreatment is not needed because the biomass with the low lignin content can be well digested. Nutrients in the biomass remain in the digestate, and are recycled to greenhouse as fertilizer [20] for biomass production, which maintains the mass balance of the whole process, because some floating aquatic plants, such as water hyacinth, can grow well in wastewater with high yield, remove organic pollution and nutrient simultaneously as observed [21]. The $\mathrm{CO}_{2}$ is not only the main by-product of the biomass conversion process, but also the main reactant to photosynthesize the biomass. It is helpful for biomass production to increase the $\mathrm{CO}_{2}$ concentration in greenhouse [22], so $\mathrm{CO}_{2}$ is recycled to the greenhouse. The biomass production and conversion, as well as the waste treatment, are integrated in the proposed process, the produced biomass is the feedstock of conversion bioreactor, and the digestate generated by the biomass conversion process, in turn, provides the fertilizer for biomass growth to guarantee a high yield of biomass; the pollution produced from the bioconversion process is removed by the aquatic plant during biomass production without additional waste treatment. The surplus heat from power generation can be applied for heating the digester or pond water. Both energy input and output come from sunlight during the bioenergy production. The methane or electricity is generated through the proposed process. As methane can also be used in automobiles to replace liquid fuel [19], the process can provide energy to replace fossil fuels. External substance and energy provision are hardly needed during the daily operation of the proposed process for production of electricity except solar energy; only carbon dioxide and solar energy are needed for production of methane, but it can be supplied by air, so it is sustainable.

\section{Net Energy Analysis}

The net annual energy yield per unit land of the integrated process is evaluated to estimate the land area requirement to produce biofuel for global transportation or electricity instead of fossil fuel. It equals the total energy produced minus energy input for the bioenergy production on a unit land in a year. The total energy produced annually on a unit land is decided by the annual yield of the biomass per unit land and energy conversion efficiency of the biomass to the methane. Energy input is the sum of the energy consumed annually by the biomass production, transportation and conversion per unit land, it is provided with the methane which is converted to electricity and heat for energy consumption 
of the process. We evaluated a water hyacinth production and conversion to produce methane or power in a $15 \mathrm{~km}^{2}$ tropical pond. A detailed estimation of the processes is fulfilled with a Microsoft excel sheet.

Estimation of water hyacinth yield: Water hyacinth is listed as one of the most productive plants on Earth, and can grow well in tropical area for the whole year [21,23]. A wide range of values for the productivity of this plant have been registered in the literature (Table 1). These values were calculated in different ways [24]. Knipling et al. [25] estimated that the annual production could be as high as 269 dry t/ha. Wolverton and McDonald determined a seven-month biomass production of 154 dry t/ha when water hyacinth grew in wastewater treatment pond in south Mississippi, USA [21]. It is mainly related to the water temperature and nutrient concentration. In the present process, the digestate is recycled to maintain the high nutrient concentration of the pond; a greenhouse is built to maintain the water temperature. We use $154 \mathrm{dry} \mathrm{t} / \mathrm{ha}$ as an annual yield of present case, which is a conservative estimation, and will be increased by $20 \%$ for the future (2040) in optimum conditions especially adding a greenhouse for the plant growth. It is more than 20 times that of the grass in the US Midwest, which is only about $7 \mathrm{t} / \mathrm{ha}[8]$.

Table 1. Water hyacinth yield reported in the literature.

\begin{tabular}{|c|c|c|c|c|}
\hline Reporter & Biomass Yield (dry t/ha/year) & Growth Condition & Growth Location & Ref. \\
\hline $\begin{array}{l}\text { Wolverton and } \\
\text { McDonald }\end{array}$ & 154 (in 7 month) & $\begin{array}{c}\text { Determined from } \\
\text { wastewater } \\
\text { treatment } \\
\end{array}$ & $\begin{array}{c}\text { Hancock and Lucedale } \\
\text { Mississippi }\end{array}$ & [21] \\
\hline Gutiérrez et al. & 140 & Eutrophic lake & $\begin{array}{c}\text { Requena Dam north } \\
\text { latitude } 19^{\circ} 57^{\prime} \\
\end{array}$ & [26] \\
\hline Knipling & 269 & $\begin{array}{l}\text { Estimation for } \\
\text { optimum condition }\end{array}$ & & [25] \\
\hline Wooten and Dodd & 106 (290kg/ha/day) & $\begin{array}{l}\text { Determined from } \\
\text { treated sewage }\end{array}$ & Ames, Iowa & [27] \\
\hline $\begin{array}{l}\text { Yount and } \\
\text { Crossman }\end{array}$ & 197 (540 kg/ha/day) & $\begin{array}{l}\text { Determined for } \\
\text { eutrophic lake }\end{array}$ & & [28] \\
\hline
\end{tabular}

\section{Estimation of energy conversion efficiency for conversing water hyacinth to biogas:} Conversing biomass to biogas or methane is a well established technology [17,20]. The possibility of converting water hyacinth to biogas has also emerged as an area of major interest for many years [29]. Productivity of up to $670 \mathrm{~L}$ biogas per kilogram volatile water hyacinth have been reported, which indicates that more than $90 \%$ energy conversion efficiency has been achieved [30] (Table 2). Generally, the lignin in plants cannot be converted to bioethanol through fermentation; however, only about $3 \%-6 \%$ of the water hyacinth is lignin [21], which is much lower than the $20 \%-50 \%$ of lignin in grass or wood. The water hyacinth has much more protein and fat than grass or wood, which cannot be converted to ethanol, but most of the components in water hyacinth including protein, fat and part of lignin can be digested to biogas [31,32], so high efficiency is easily obtained; for example, up to $95.7 \%$ energy conversion efficiency [33] was obtained using the mixture of activated sludge and water hyacinth. Here we use $12 \mathrm{~L}$ methane/kg fresh water hyacinth or $240 \mathrm{~L}$ methane/kg dry biomass for the present methane production which is equal to $62 \%$ energy conversion efficiency, which is much less than the experimental result [30], and much better than bioethanol process or other processes [15]. It will 
increase to $18 \mathrm{~L} / \mathrm{kg}$ (about 93\% energy conversion efficiency) fresh biomass or $360 \mathrm{~L} / \mathrm{kg}$ dry biomass in the future [21] which is also less than the present experimental data [33].

Table 2. Methane yield of the water hyacinth by anaerobic digestion reported in literature.

\begin{tabular}{ccccc}
\hline Report & Methane Yield & Reactor & Energy Conversion Yield & Reference \\
\hline $\begin{array}{c}\text { Chin and } \\
\text { Goh (1978) }\end{array}$ & $\begin{array}{c}\text { gas 0.67 L/g volatile, } \\
60 \% \text { methane }\end{array}$ & Lab and field scale & $90.0 \%$ & {$[30]$} \\
\hline $\begin{array}{c}\text { Kivaisi and } \\
\text { Mtila (1998) }\end{array}$ & $\begin{array}{c}\text { Biogas with } 80 \% \mathrm{CH}_{4} ; \\
\text { average yield 0.44 L/g } v s\end{array}$ & $\begin{array}{c}\text { Biphasic reactor (rumen } \\
\text { reactor + UASB) }\end{array}$ & $78.8 \%$ & {$[34]$} \\
\hline $\begin{array}{c}\text { Beljetina, } \\
1987\end{array}$ & $0.49 \mathrm{~L}$ methane/g $v s$ & $\begin{array}{c}\text { Non-mixed vertical } \\
\text { flow reactor }\end{array}$ & $95.7 \%$ & {$[33]$} \\
\hline
\end{tabular}

Based on the above water hyacinth yield and methane conversion efficiency, the gross methane yield per unit land was estimated as $36,220.8 \mathrm{~m}^{3} / \mathrm{a} / \mathrm{h}$ and $65,197.4 \mathrm{~m}^{3} / \mathrm{a} / \mathrm{h}$ which are equal to 41.2 and $74.1 \mathrm{~kW} / \mathrm{h}$ for the present and future cases respectively. The gross energy of produced methane of the whole system is $1.947 \times 10^{9} \mathrm{MJ} / \mathrm{a}$ and $3.505 \times 10^{9} \mathrm{MJ} / \mathrm{a}$ which is equal to 61.75 and $111.15 \mathrm{MW}$ respectively for the present and future cases respectively.

Energy input for biomass production is generally consumed by the following processes: production and transportation of seed, herbicide, pesticide and fertilizer [35]. Water hyacinth reproduces sexually by seeds or vegetatively by budding and stolon production. For the sake of rapid spread, the vegetative propagation is more important [29,36], so seed is not necessary for water hyacinth production especially in tropical area or greenhouse. Water hyacinth is considered to be one of the worst weeds and is difficult to control because of its high growth rate [29]. Under favorable conditions of sunlight, temperature and nutrient, the vegetative propagation is very fast [29], so herbicide and pesticide will be seldom used. The anaerobic residue and liquid effluent from digestion of biomass are used as fertilizers directly [20]. The nutrient in the system can be well recycled because it is enclosed in a greenhouse with a waterproof pond. The loss way of nitrogen fertilizer is the conversion of ammonia to nitrogen which happens in the following way: first, ammonia is nitrified aerobically in the water of pond under low organic concentration, and then converted to nitrogen through denitrification under high organic concentration and anoxic condition. Therefore, it is hard to meet all conditions to emit the nitrogen in the pond or digester. It was reported that $\mathrm{N}_{2} \mathrm{O}$ emitted from denitrification is hardly detected in a similar case of the water submersed rice paddy [37]. Therefore, conversion of ammonia to nitrogen will hardly happen in the present water submersed pond. Ammonia emitted to biogas in the digester can be less than 9 ppm by controlling $\mathrm{pH}$ [38], and be scrubbed partly through water washing process for methane purification and entered pond again in greenhouse. Therefore, we ignore the loss of nitrogen fertilizer in the whole process. The potassium and phosphate exist in solid and liquid phases in the system and are also recycled very well after initial provision. Therefore, chemicals are hardly needed, the related energy input for water hyacinth production is very little and can be ignored.

Energy input for water hyacinth transport in the pond: An open-closed ditch is used for biomass production in greenhouse, in which an underwater propeller is used to drive water flow in the ditch. This kind of design also promotes the growth of the water hyacinth as the nutrient in the pond 
can be better absorbed by the water hyacinth. The floating aquatic plant is transported by the flowing water to fixed position to be collected, crushed to slurry, and pumped to digester. Energy input is consumed by the propeller; collecting equipment and transportation pump for collection and transportation of the water hyacinth. Energy consumed by propeller is used to drive the water in the ditch to overcome the water flow resistance. It is estimated with Rozovskii's equation for additional water head loss of curve ditch and Chezy's equation for straight ditch [39].

$$
E=Q \times g \times h / \eta=W H v \times g \times\left[\left(24 \frac{\sqrt{g}}{C}+60 \frac{g}{C^{2}}\right) \frac{H^{2}}{r^{2}} \frac{L}{H}+\frac{2 g}{C^{2}} \frac{L}{R}\right] \frac{v^{2}}{2 g} / \eta
$$

where $\mathrm{Q}$ is the flow rate across the section of the ditch $(\mathrm{L} / \mathrm{s}), \mathrm{g}=9.8 \mathrm{~m}^{2} / \mathrm{s}$, the gravitational accelerated velocity, $\mathrm{h}$ is the head loss of the water, $\eta=10 \%$, is the efficiency of the propeller which comes from the analysis of the experimental data of the propeller in the oxidation ditch for wastewater treatment, $\mathrm{W}=2000 \mathrm{~m}$, is the width of the ditch, $\mathrm{H}=1 \mathrm{~m}$, is the depth of the water in the ditch, $\mathrm{v}=0.04 \mathrm{~m} / \mathrm{s}$ is the flow velocity of the water in the ditch which is determined by the maximum growth rate, here assuming that the biomass doubles in about 2 days. $\mathrm{C}=\mathrm{R}^{1 / 6} / \mathrm{n}$, where $\mathrm{R} \approx \mathrm{H}$ is the hydraulic radius; $n=0.0225$ is the Manning roughness; $\mathrm{L}=2 \times \pi \mathrm{r}$, is the circumference of the ditch at the center line, $\mathrm{r}=\mathrm{W} / 2=1000 \mathrm{~m}$, is the half radii of the ditch.

The calculated energy input for water hyacinth transport in the pond is $39.9 \mathrm{~kW}$, which comes mainly from the head loss of the water flow; the additional loss from the bend is very small.

The energy input for collecting water hyacinth is estimated as 213.0 and $204.5 \mathrm{~kW}$ for the present and future respectively, according to Woverton's experimental results which is $33.44 \mathrm{kWh} / \mathrm{t}$ [21], and a $20 \%$ reduction assumed for the future.

Energy input for crushing water hyacinth is estimated to be 565.0 and $678.0 \mathrm{~kW}$ for the present and future respectively, according to the crushing of switchgrass which is $5 \mathrm{~kW} / \mathrm{MW}$ biomass [40].

The energy input for transportation of water hyacinth slurry to digester through pumping is estimated according to the Hazen-Williams equation [41] which is used for estimating energy loss in pipe transportation of activated sludge as following.

$$
E=Q \times g \times h / \eta=\pi r^{2} v \times g \times 6.82 C\left(\frac{L}{2 r}\right)^{1.17} \frac{v^{2}}{C_{h}^{2}} / \eta
$$

where $\mathrm{r}=0.254 \mathrm{~m}$, is the radius of the transportation pipe, $\mathrm{v}=1 \mathrm{~m} / \mathrm{s}$, is the transportation velocity, $\mathrm{C}=\mathrm{R}^{1 / 6} / \mathrm{n}$, where $\mathrm{R}=0.254 \mathrm{~m}$, is the hydraulic radius; $n=0.011$ is the Manning roughness; $\mathrm{L}=1000 \mathrm{~m}$, is the transportation pipe length, $\mathrm{Ch}_{h}=53$, is the Hazen-Williams coefficient, $\eta=50 \%$, is the efficiency of the pump from the relevant technical data.

The calculated energy input for pumping the water hyacinth slurry to digester is 36.8 and $39.8 \mathrm{~kW}$ for the present and future respectively.

Energy input for biomass conversion: The digester is designed according to a non-mixed vertical flow reactor with operation temperature of $30-35{ }^{\circ} \mathrm{C}$ [33]. Energy input includes heating digester, pumping the crushed biomass into reactor, mixing and pumping liquid effluent and solid residue from anaerobic digester to pond for recycling. Pumping energy for recycling liquid effluent and solid residue from anaerobic digester back to pond is set to be the same as that of biomass transportation. Power input for mixing and pumping of digester during the biomass conversion is $1464.4 \mathrm{~kW}$ for the 
present case and $1757.3 \mathrm{~kW}$ for the future case, which is about $2.3 \%$ of the produced methane in the anaerobic digestion process as presented in the previous study [42]. Heat input for heating the biomass is ignored as the system is assumed to work in a tropical greenhouse. Pretreatment is not necessary in digestion of water hyacinth because of its low lignin components, although much energy is needed to overcome the recalcitrant nature of wood or grass which hinders the access to its molecular building blocks due to high lignin content [9].

For upgrading biogas to methane, power energy input is estimated as 3223.0 and $5801.4 \mathrm{~kW}$, and heat energy input is estimated as 1054.8 and $1898.6 \mathrm{~kW}$ for the present and future respectively, based on the energy input data for power and heat input of 1.1 and $0.36 \mathrm{MJ} / \mathrm{m}^{3}$ biogas respectively [43].

Total power energy input of the whole system is $5586.8 \mathrm{~kW}$ and $8568.4 \mathrm{~kW}$, and the total heat input is 1054.8 and $1898.6 \mathrm{~kW}$ for the present and future respectively. Assumed that part of the methane is used for generation of electricity and heat to meet the energy input, $50 \%$ and $60 \%$ power efficiency for the present and future respectively, and 90\% heat efficiency [44], the total energy input from the whole system is $12,345.6$ and $16,390.2 \mathrm{~kW}$ or 1685.4 and $1864.7 \mathrm{MJ} / \mathrm{t}$ dry biomass for the present and future respectively. The energy input of the process is summarized in Table 3.

We compare the energy input of the integrated biomethane process with the switchgrass to bioethanol process as listed in Table 3. The input energy data for bioethanol is from the GREET model 2014. GREET [45] (Greenhouse gases, Regulated Emissions, and Energy use in Transportation) is a full life-cycle model sponsored by the Argonne National Laboratory. For the switchgrass to bioethanol process, according to the GREET model, the energy input for operation of the refinery plant is provide with the fermentation residue which keep more than half of the biomass energy; but for the integrated biomethane process, the digestion residue is not recycled for energy, the energy in residue is abandoned. However, the energy input for the ordinary bioethanol process is still much more than that of the integrated biomethane process, as much more energy is need to produce various Chemicals for the operation of the bioethanol process while no chemicals are needed for operation of the integrated biomethane process.

Table 3. Energy input for production of bioethanol and methane from plantation of switchgrass and water hyacinth through fermentation and digestion respectively.

\begin{tabular}{|c|c|c|c|c|}
\hline \multirow[t]{2}{*}{ Phase } & \multirow[t]{2}{*}{ Input Item } & \multicolumn{2}{|c|}{ Switchgrass to Ethanol } & \multirow{2}{*}{$\begin{array}{c}\text { Water Hyacinth to Methane } \\
\text { MJ/t biomass }\end{array}$} \\
\hline & & GREET [45] data (btu/t) & MJ/t biomass & \\
\hline \multirow[t]{8}{*}{ farm } & Operation * & $261,538.00$ & 275.92 & 71.15 \\
\hline & nitrogen & $494,658.00$ & 521.86 & 0 \\
\hline & $\mathrm{P}_{2} \mathrm{O}_{5}$ & 2389.00 & 2.52 & 0 \\
\hline & $\mathrm{K}_{2} \mathrm{O}$ & 1944.00 & 2.05 & 0 \\
\hline & herbicide & 8342.00 & 8.80 & 0 \\
\hline & HDPE for storage & $25,846.00$ & 27.27 & 0 \\
\hline & Transportation to plant & $180,690.00$ & 190.63 & 10.08 \\
\hline & total & $976,208.83$ & 1029.90 & 81.23 \\
\hline \multirow[t]{3}{*}{ refinery } & Cellulase & $775,056.57$ & 817.68 & 0 \\
\hline & Yeast & $103,057.10$ & 108.73 & 0 \\
\hline & Sulfuric & $18,951.83$ & 19.99 & 0 \\
\hline
\end{tabular}


Table 3. Cont.

\begin{tabular}{|c|c|c|c|c|}
\hline \multirow[t]{2}{*}{ Phase } & \multirow[t]{2}{*}{ Input Item } & \multicolumn{2}{|c|}{ Switchgrass to Ethanol } & \multirow{2}{*}{$\begin{array}{c}\text { Water Hyacinth to Methane } \\
\mathrm{MJ} / \mathrm{t} \text { biomass }\end{array}$} \\
\hline & & GREET [45] data (btu/t) & MJ/t biomass & \\
\hline & Ammonia & $150,448.41$ & 158.72 & 0 \\
\hline & Corn & $1,129,545.63$ & 1191.67 & 0 \\
\hline & $\left(\mathrm{NH}_{4}\right)_{2} \mathrm{HPO}_{4}$ & $22,335.36$ & 23.56 & 0 \\
\hline & $\mathrm{NaOH}$ & $345,650.28$ & 364.66 & 0 \\
\hline & $\mathrm{CaO}$ & $32,557.15$ & 34.35 & 0 \\
\hline & Urea & $55,740.77$ & 58.81 & 0 \\
\hline & Diesel & $17,625.89$ & 18.60 & 0 \\
\hline & Grinding of biomass & from residue & 0 & 154.28 \\
\hline & Operation of reactor & from residue & 0 & 399.84 \\
\hline & waste transportation & from residue & 0 & 10.08 \\
\hline & Purification of biofuel & from residue & 0 & 1040.00 \\
\hline & total & & 2796.77 & 1604.19 \\
\hline & coproducts & $-1,697,539.76$ & -1790.90 & 0 \\
\hline total & & & 2034.92 & 1685.42 \\
\hline
\end{tabular}

* including all activity in farm, biomass harvest/collection; drying; storage etc.

\section{Results}

After subtracting the energy input, the total net methane produced in the whole system for $15 \mathrm{~km}^{2}$ land is $49.40 \mathrm{MW}$ and $94.76 \mathrm{MW}$ or 43.5 and 83.4 million $\mathrm{m}^{3} /$ year for the present and future respectively. Therefore, the net annul methane yield per unit land is $28,979.0$ and $55,583.1 \mathrm{~m}^{3} / \mathrm{ha}$ respectively for the present and future. For the present cases, the average daily energy flow of the whole system for the plantation of water hyacinth and digested to methane or further converted to electricity is summarized and shown in Figure 2, 29,800 $\mathrm{m}^{3} /$ day methane is used to produce electricity and heat for operation of the system, the average output of the whole system is estimated to $119.1 \mathrm{~km}^{3}$ methane/day. If the methane is conversed to electricity, the average output electricity of the whole system is $592.8 \mathrm{MWh} /$ day.

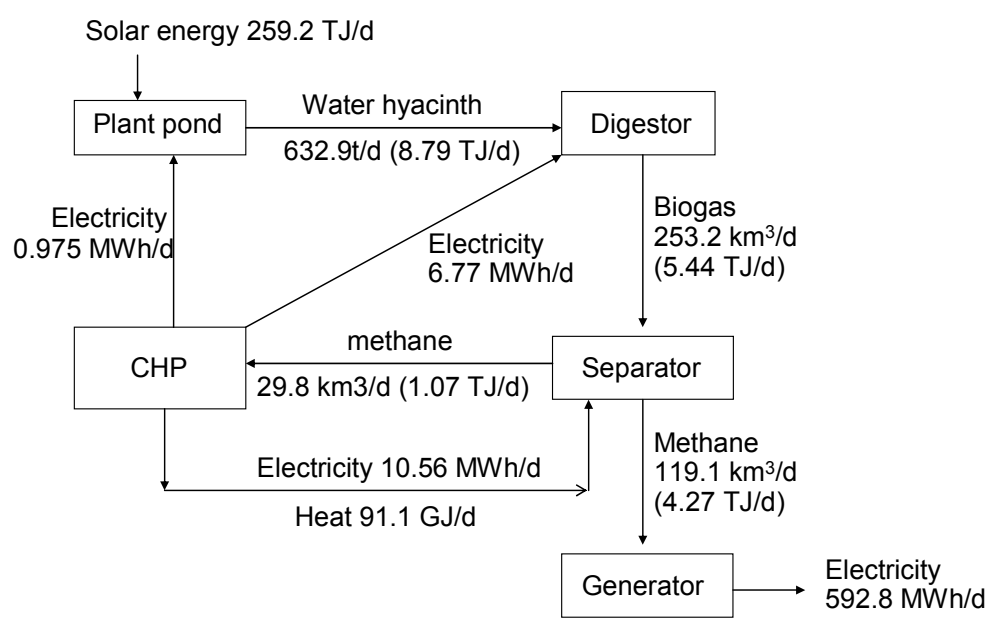

Figure 2. Average daily energy flow for the plantation of water hyacinth and digested to methane or further converted to electricity. 
For the present case, the annual yield of bioethanol and methane from plantation of switchgrass and water hyacinth through fermentation and digestion, respectively, are summarized in Table 4. The estimated results show that the yield of the integration process to produce methane for unit land is 20 times more than that of the ordinary bioethanol process; the main reason includes the high biomass yield, the high biofuel yield and low loss rate of the integrated water hyacinth to methane process. The high energy input of the ordinary bioethanol process is offset by the high energy of the residue which is related to the low biofuel yield. For ordinary bioethanol process, the energy input is about $5 \mathrm{MJ} / \mathrm{kg}$ biomass [10] to produce sugar through hydrolysis of the cellulose, which is equal to $78 \%$ energy of the biofuel it produced, so the increased actual bioenergy output of the proposed integrated process should also be attributed to the low energy input, which is less than $20 \%$ energy of the biomethane it produced.

Table 4. The present annual yield of bioethanol and methane from plantation of switchgrass and water hyacinth through fermentation and digestion respectively.

\begin{tabular}{cccc}
\hline Item & Unit & Switchgrass to Ethanol & Water Hyacinth to Methane \\
\hline biomass yield & ton/ha/year & $13.45[1]$ & 154.00 \\
loss rate $*$ & & 0.206 & 0.02 \\
biofuel yield & L/kg biomass & 0.3028 & 240 \\
& $\mathrm{MJ} / \mathrm{t}$ biomass & 6442.25 & 8429.85 \\
& $\mathrm{MJ} / \mathrm{ha} /$ year & $68,838.13$ & $1,298,197$ \\
net biofuel yield & $\mathrm{MJ} / \mathrm{t}$ biomass & 4407.33 & 6744.43 \\
& $\mathrm{MJ} /$ ha/year & $47,094.1$ & $1,038,643$ \\
& $\mathrm{~m}^{3} / \mathrm{ha} /$ year & 2.2135 & $28,979.0$ \\
\hline
\end{tabular}

* Loss rate for bioethanol production includes field treatment $2 \%$; field drying $5 \%$; harvest $/$ collection $5 \%$; farm handling $2 \%$; storage $8.4 \%$; road transport $2 \%$ of biomass which is provided by GREET 2014 model; loss rate for methane production come from the purification of methane.

For a bioethanol biorefinery, only about $2.5 \mathrm{ML}$ bioethanol $(\approx 50$ million $\mathrm{MJ})$ is usually produced in a year [8] because the transportation energy input and cost limit the scale due to the low yield, but with the integrated process we proposed, it is easy to produce methane with ten times energy in the same land because of the higher energy yield. The larger scale of biorefinery plant can decrease the product cost, make the proposed process more competitive in energy markets.

Methane can replace gasoline for automobiles as fuel, such as in Sweden, 10\% biogas is purified to methane and used for transportation fuel [19]. According to the global crude oil consumption of 88.8 million barrels per day in 2012 [3], we estimate that the land area required to produce sufficient methane to replace the global transportation fuel demand is 1.65 million $\mathrm{km}^{2}$, only covers $1.10 \%$ of the land area of the earth for the present, and their values are 1.06 million $\mathrm{km}^{2}, 0.71 \%$ respectively for the future (Table 5). The land area requirement for the proposed biofuel production process is much lower than any other bioenergy processes. 
Table 5. Land requirements for replacement of automobile fuel with the proposed process.

\begin{tabular}{ccc}
\hline Item & Present 2012 & Future 2040 \\
\hline Methane generated for unit land $\left(\mathrm{m}^{3} / \mathrm{ha} /\right.$ year) & 28,979 & 55,583 \\
\hline $\begin{array}{c}\text { Liquid fuel consumption for world } \\
\text { (million barrel/day) }\end{array}$ & 88.8 & 109.4 \\
\hline Required Land For world (million $\left.\mathrm{km}^{2}\right)$ & 1.65 & 1.06 \\
\hline Required Land For USA (million $\left.\mathrm{km}^{2}\right)$ & 0.34 & 0.18 \\
\hline Required Land For China (million $\left.\mathrm{km}^{2}\right)$ & 0.19 & 0.18 \\
\hline
\end{tabular}

For a power generation scheme with the proposed process, according to $50 \%$ power conversion efficiency for the present case and $60 \%$ for the future case through the combined gas and steam cycle power generation system [44], it is estimated that the net electricity generated by the whole system is 216 and 498 million $\mathrm{kWh}$ per year for the present and future case respectively. Therefore, the annual power generation yield per unit land is 14.5 and 33.3 million $\mathrm{kWh} / \mathrm{km}^{2}$ respectively for the present and future. Therefore, the land area required to meet the global power demand [3] with the proposed process is 1.48 million $\mathrm{km}^{2}$ for the present, 1.18 million $\mathrm{km}^{2}$ for the future. This means that only $1.00 \%$ and $0.79 \%$ of world's land are needed to meet the global power consumption at present and future respectively (Table 6).

Table 6. Land requirements for power generation with the proposed process.

\begin{tabular}{ccc}
\hline Case & Present 2012 & Future 2040 \\
\hline Net Power yield (million $\mathrm{kWh} / \mathrm{km}^{2} /$ year) & 14.5 & 33.3 \\
Power consumed in the world (billion $\mathrm{kWh} / \mathrm{year})$ & 21,413 & 39,030 \\
Required Land For world (million $\mathrm{km}^{2}$ ) & 1.48 & 1.17 \\
Required Land For USA (million $\mathrm{km}^{2}$ ) & 0.27 & 0.15 \\
Required Land For China (million $\mathrm{km}^{2}$ ) & 0.33 & 0.35 \\
\hline
\end{tabular}

If the methane produced through the proposed process is applied to replace liquid oil, then the carbon dioxide emission of liquid fuel will be reduced effectively, because the present integrated process use the carbon dioxide in air to produce transportation fuel, so the carbon dioxide in air is reduced in the production of the biomethane, the carbon dioxide released by burning it has been offset by the production of the biomethane. The global emission of carbon dioxide in 2012 caused by burning liquid fuel is 11.34 billion tons, which accounts for $35.4 \%$ of the total carbon dioxide emission of the world [3]. Therefore, we can reduce $35.4 \%$ of carbon dioxide emission of the world with the proposed process to produce methane to replace liquid fuel.

If the proposed process is applied to power generation to replace the present fossil fuel, then the carbon dioxide emission from the present fossil fuel power plants can be avoided. It is reported that the total carbon dioxide emission of the US in 2011 is 5.47 billion tons [46], in which 2.17 billion tons are generated by the fossil fuel power plant [46]. Therefore, the amount of carbon dioxide emission in US will be reduced by $39.6 \%$ if the present power plant is replaced with the proposed process for 2011 . 


\section{Discussion and Conclusions}

The biomethane yield and energy input for the operation of the system including the plantation and digestion of the water hyacinth are analyzed to estimate the net energy of the unit land produced through the present integrated process. The energy input for plant building and equipment making is ignored, as it is averaged to each liter fuel produced in the whole life of the system which is less than $1 \%$ energy input of the operation such as in corn fermentation to bioethanol [1].

The results indicate that there are a number of important consequences of the proposed processes. First, there is no net $\mathrm{CO}_{2}$ emission if the proposed process is applied to produce electricity or methane, because carbon dioxide is utilized for photosynthesis in the biomass production and recycled for plant growth, it offset the generation of carbon dioxide from the burning of the methane for power generation or as biofuel of automobiles. Second, the application of the anaerobic waste to the biomass production, not only disposes the waste produced by the digestion of biomass, but also provides fertilizer for the production of biomass. It will reduce the energy input in both production and conversion of the biomass, increase the net energy yield so as to decrease the land demand for bioenergy production to replace fossil fuel. Third, the additional fertilizers from outside of the greenhouse are hardly needed in daily operation, so the pollution and energy input from production of the fertilizers is avoided. Fourth, there is no wastewater discharged during the operation of the proposed process, so the occurrence of water eutrophication is avoided. Fifth, $\mathrm{CO}_{2}$ can be used to promote the yield of the biomass, it will reduce the land requirement and emission of the greenhouse gas in the present process as the carbon dioxide produced in the bioconversion process is recycled to the greenhouse for biomass production. Sixth, water floating plants grow and are collected daily in tropical areas, so as to reduce energy input for the storage of biomass. Seventh, a pipeline is used for transportation of anaerobic digestate and water floating plants, which are crushed into slurry, so as to reduce the energy input as well as the cost of the biomass and digestate transportation. Eighth, the initial fertilizer for the water hyacinth production can be obtained from the domestic sewage and waste, no additional facility is needed to supply the fertilizer for the energy crop production. Ninth, domestic wastewater can be treated in a plant pond and organic waste can be treated in an anaerobic digester, so it can provide help for improving the environment. Tenth, ecology around the system will be hardly damaged, because the substance and energy in the greenhouse are hardly interchanged with external environment. Eleventh, a waterproof treatment is designed and built for the plant pond to avoid the loss of fertilizer and water, so marginal land can be used for biomass production to avoid competing with food production, and no land degradation will occur as plants grow in a pond within a greenhouse.

Integrated water hyacinth production and anaerobic digestion process for bioenergy has a rather high net energy yield per unit land. It can be attributed as follows: first, the water hyacinth can grow well in wastewater treatment pond [21] with nutrient available in digestate, and is one of the highest yield plants [23] which is ten to twenty times as many as that of the grass in US Midwest [8]. It can be increased further in a closed greenhouse with high $\mathrm{CO}_{2}$. Second, anaerobic digestion can transform all bioorganic matters except un-hydrolyzed lignin [31,32]; however, as the lignin content in water hyacinth is rather low as 3\%-6\% [21], so energy conversion efficiency can reach $95.7 \%$ for anaerobic digestion of water hyacinth [33]. Third, the energy input for water hyacinth production and 
pretreatment can be ignored; energy input for digestion and biogas upgrading is less than $20 \%$ of the products, so the net bioenergy yield can be much more than any other processes [11,15]. Considering the actual factors, such as water-availability, infrastructure etc., the required land may be more than the present estimation.

The solar power conversion efficiency of the proposed process is estimated as $1.65 \%$ for the present case and $3.16 \%$ for the future case, it is much lower than that of the solar cell; however, the main technologies used in the proposed process, including anaerobic digestion, have been applied for a long time and have low capital and operation costs, so they may be a good alternative before a low cost photovoltaic technology is developed [47].

In summary, the proposed process integrates biomass production and conversion process to provide a high yield of alternative sustainable bioenergy per unit land. The key technology of anaerobic digestion is rather mature and widely used before in treatment of organic waste. Agriculturally marginal land can be used for biomass production, so it will not compete with food production. Nearly no harmful substance is emitted to damage the present economical activities and the environment. However, we need to further validate it on a large scale. Further improvements can be envisaged to increase the efficiency of the process, if the digestion mechanism of water hyacinth is better understood.

\section{Acknowledgments}

The financial support (07010302166) from department of science and technology of Anhui is greatly appreciated.

\section{Conflicts of Interest}

The author declares no conflict of interest.

\section{Reference}

1. Farrell, A.E.; Plevin, R.J.; Turner, B.T.; Jones, A.D.; O’Hare, M.; Kammen, D.M. Ethanol can Contribute to Energy and Environmental Goals. Science 2006, 311, 506-508.

2. Marquardt, W.; Harwardt, A.; Hechinger, M.; Kraemer, K.; Viell, J.; Voll, A. The biorenewables opportunity-Toward next generation process and product systems. AIChE J. 2010, 56, 2228-2235.

3. EIA. International Energy Outlook; EIA, Department of Energy: Washington, DC, USA, 2013.

4. Fedoroff, N.V.; Cohen, J.E. Plants and population: Is there time? Proc. Natl. Acad. Sci. USA 1999, 96, 5903-5907.

5. Tilman, D.; Hill, J.; Lehman, C. Carbon-negative biofuels from low input high diversity grassland biomass. Science 2006, 314, 1598-1600.

6. Hill, J.; Nelson, E.; Tilman, D.; Polasky, S.; Tiffany, D. Environmental, economic, and energetic costs and benefits of biodiesel and ethanol biofuels. Proc. Natl. Acad. Sci. USA 2006, 103, $11206-11210$.

7. Somerville, C.; Youngs, H.; Taylor, C.; Davis, S.C.; Long, S.P. Feedstocks for lignocellulosic biofuels. Science 2010, 329, 790-792. 
8. Gelfand, I.; Sahajpal, R.; Zhang, X.; Izaurralde, R.C.S.; Gross, K.L.; Robertson, G.P. Sustainable bioenergy production from marginal lands in the US Midwest. Nature 2013, 493, 514-517.

9. Chundawat, S.P.S.; Beckham, G.T.; Himmel, M.E.; Dale, B.E. Deconstruction of Lignocellulosic Biomass to Fuels and Chemicals. Ann. Rev. Chem. Biomol. Eng. 2011, 2, 121-145.

10. Viell, J.; Harwardt, A.; Seiler, J.; Marquardt, W. Is biomass fractionation by Organosolv-like processes economically viable? A conceptual design study. Bioresour. Technol. 2013, 150, 89-97.

11. Agrawal, R.S.N.; Ribeiro, F.; Delgass, N. Sustainable fuel for the transportation sector. Proc. Natl. Acad. Sci. USA 2007, 104, 4828-4833.

12. Turner, J.A. Sustainable hydrogen production. Science 2004, 305, 972-974.

13. Kendall, A.; Yuan, J. Comparing life cycle assessments of different biofuel options. Curr. Opin. Chem. Biol. 2013, 17, 439-443.

14. Towler, G.P.; Oroskar, A.R.; Smith, S.E. Development of a sustainable liquid fuels infrastructure based on biomass. Environ. Prog. 2004, 23, 334-341.

15. Huang, W.; Zhang, Y.-H.P. Energy Efficiency Analysis: Biomass-to-Wheel Efficiency Related with Biofuels Production, Fuel Distribution, and Powertrain Systems. PLoS One 2011, 6, e22113-e22122.

16. Dael, M.V.; Passel, S.V.; Pelkmans, L.; Guisson, R.; Reumermann, P.; Luzardo, N.M.; Witters, N.; Broeze, J. A techno-economic evaluation of a biomass energy conversion park. Appl. Energy 2013, 104, 611-622.

17. Klass, D.L. Methane from Anaerobic Fermentation. Science 1984, 223, 1021-1028

18. Krich, K.; Augenstein, D.; Batmale, J.P.; Beneman, J.; Rutledge, B.; Salour, D. Biomethane from Dairy Waste, a Sourcebook for the Production and Use of Renewable Natural Gas in California; Sustainable Conservation: San Francisco, CA, USA, 2005.

19. Borjesson, P.; Berglund, M. Environmental systems analysis of biogas systems-Part II: The environmental impact of replacing various reference systems. Biomass Bioenergy 2007, 31, 326-344.

20. Beck, R.W.I. Anaerobic Digestion Feasibility Study. Bluestem Solid Waste Agency and Iowa Department of Natural Resources; Bluestem Solid Waste Agency: St. Paul, MN, USA, 2004.

21. Wolverton, B.C.; McDonald, R.C. Water hyacinth productivity and harvesting studies. Econ. Bot. 1979, 33, 1-10.

22. Bloom, A.J.; Smart, D.R.; Nguyen, D.T.; Searles, P.S. Nitrogen assimilation and growth of wheat under elevated carbon dioxide. Proc. Natl. Acad. Sci. USA 2002, 99, 1730-1735.

23. Gutiérrez, E.L.; Ruiz, E.F.; Uribe, E.G.; Martínez, J.M. Biomass and Productivity of Water Hyacinth and Their Application in Control Programs. In Proceedings of the ACIAR, Biological and Integrated Control of Water Hyacinth, Eichhornia crassipes, Beijing, China, 9-12 October 2000.

24. Knipling, E.B.; West, S.H.; HaIler, T.W. Growth characteristics, yield potential, and nutritive content of waterhyacinths. Soil Crop Sci. Soc. Fla. 1979, 30, 198-212.

25. Wooten, J.W.; Dodd, J.D. Growth of water hyacinth in treated sewage effluent. Econ. Bot. 1976, 30, 29-37.

26. Yount, J.L.; Crossman, R.A., Jr. Eutrophication control by plant harvesting. J. Water Pollut. Control Fed. 1970, 42, R173-R183.

27. Abbasi, S.; Ramasamy, E. Biotechnological Methods of Pollution Control; Orient Longman (Universities Press India Ltd.): Hyderabad, India, 1999. 
28. Gopal, B. Water Hyacinth. Aquatic Plant, Studies 1; Elsevier Science: Amsterdam, The Netherlands, 1987.

29. Chin, K.K.; Goh, T.N. Bioconversion of solar energy: Methane production through Water hyacinth, In Proc Second Symp Energy Biomass Waste; Institute of Gas Technology: Chicago, IL, USA, 1978; pp. 215-228.

30. Kivaisi, A.K.; Mtila, M. Production of biogas from water hyacinth (Eichhornia crassipes) (mart) (solms) in a two-stage bioreactor. World J. Microbiol. Biotechnol. 1998, 14, 125-131.

31. Biljetina, R.; Srivastava, V.J.; Chynoweth, D.P.; Hayes, T.D. Anaerobic Digestion of Water Hyacinth and Sludge; Magnolia Pubulisher Inc.: Orlando, FL, USA, 1987; pp. 725-738.

32. Malik, A. Environmental challenge vis a vis opportunity: The case of water hyacinth. Environ. Int. 2007, 33, 122-138.

33. Stronach, S.M.; Rudd, T.; Lester, J.N. Anaerobic Digestion Processes in Industrial Wastewater Treatment; Springer-Verlag: Berlin, Germany, 1986.

34. Gerardi, M.H. The Microbiology of Anaerobic Digesters, Wastewater Microbiology Series 2003; John Wiley \& Sons, Inc. (US): Hoboken, NJ, USA, 2003.

35. Shapouri, H.; Duffield, J.A.; Wang, M. The energy balance of corn ethanol revisited. Trans. Asae 2003, 46, 959-968.

36. Verma, R.; Singh, S.P.; Ganesha, R.K. Assessment of changes in water hyacinth coverage of water bodies in northern part of Bangalore city using temporal remote sensing data. Curr. Sci. 2003, 2003, 792-804.

37. Yun, L.; Zheng, X. B\&W Advanced Low NOx Control Technology. In Proceedings of 2nd U.S.-China NOx and $\mathrm{SO}_{2}$ Control Workshop, Dalian, China, 2-5 August 2005.

38. Strik, D.P.B.T.B.; Domnanovich, A.M.; Holubar, P. A pH-based control of ammonia in biogas during anaerobic digestion of artificial pig manure and maize silage. Process Biochem. 2006, 41, $1235-1238$.

39. Li, W.; Xu, X. Hydrolics; Wuhan University Publish Inc.: Wuhan, China, 2000; p. 246. (In Chinese)

40. Hamelinck, C.N.; van Hooijdonk, G.; Faaij, A.P.C. Ethanol from lignocellulosic biomass: Techno-economic performance in short-, middle- and long-term. Biomass Bioenergy 2005, 28, 384-410.

41. Viessman, W., Jr.; Hammer, M.J. Water Supply and Pollution Control, 7th ed.; Pearson Education, Inc.: Upper Saddle River, NJ, USA, 2005,

42. Chynoweth, D.P. Biomass Conversion Options; Magnolia Publ. Inc.: Orlando, FL, USA, 1987; pp. 621-642.

43. Pöschl, M.; Ward, S.; Owende, P. Evaluation of energy efficiency of various biogas production and utilization pathways. Appl. Energy 2010, 87, 3305-3321.

44. Wang, M.; Wu, Y.; Elgowainy, A. Operating Manual for GREET: Version 1.7; Center for Transportation Research, Energy Systems Division, Argonne National Laboratory: Argonne, IL, USA, 2007.

45. Wang, M. GREET Model 1 2014. Available online: https://greet.es.anl.gov/greet_1_series (accessed on 29 Novermber 2014).

46. EIA. Annual Energy Outlook 2013 with Projections to 2040; EIA, Department of Energy: Washington, DC, USA, 2013. 
47. Lewis, N.S. Toward Cost-Effective Solar Energy Use. Science 2007, 315, 798-801.

(C) 2015 by the author; licensee MDPI, Basel, Switzerland. This article is an open access article distributed under the terms and conditions of the Creative Commons Attribution license (http://creativecommons.org/licenses/by/4.0/). 